\title{
Effects of Calcium dobesilate on horses with an increased signal intensity in the navicular bone in fat suppressed images on MRI: Pilot study
}

\author{
Imke Janssen', Tim Mair ${ }^{2}$, Richard Reardon ${ }^{3}$, Martin P. Weaver ${ }^{4}$, Christian Fricker ${ }^{5}$, Franziska Kremer ${ }^{7}$ und Christoph Lischer ${ }^{6}$ \\ Veterinary Clinic for Horses, Lüsche, Germany' ${ }^{1}$, Bell Equine Veterinary Clinic Kent, Mereworth Maidstone, University of Glasgow UK3 , School of Veterinary Medi- \\ cine, Weipers Centre for Equine Welfare, Bearsden Road, Glasgow UK ${ }^{3}$, Royal Dick School of Veterinary Studies, The University of Edinburgh, Equine Hospital, \\ Easter Bush Veterinary Centre, Roslin, Midlothian UK ${ }^{4}$, Veterinary Practice Schöfflisdorf, Switzerland ${ }^{5}$ and Free University of Berlin, Equine Clinic for Surgery and \\ Radiology, Berlin, Germany ${ }^{6}$
}

\begin{abstract}
Summary
Early stages of navicular disease (ND) in horses have been observed to be associated with chronic lameness. These early stages of disease have been recognised as increased signal intensity in fat suppressed images in the spongiosa of the navicular bone (NB). Calcium dobesilate (CD) has an effect on pressure dynamics in the subchondral bone of osteoarthritic joints of rabbits and could potentially be used as a treatment for the early stages of ND in horses. The aim of this pilot study was to monitor the lameness and the MRI changes in 12 horses diagnosed with chronic foot pain and demonstrating increased signal intensity in fat suppressed images in the spongiosa of the NB. Twelve horses with fore foot lameness of between one month and two year's duration were selected for the study. Inclusion criteria were: absence of radiographic findings on standard foot radiographs and an increased signal intensity in fat suppressed images in the spongiosa of the NB without concurrent lesions detected on MRI scans of the foot. Horses were treated with CD and a controlled exercise regimen and were re-evaluated clinically and with MRI two and four months after diagnosis. In 10 of 12 horses (83\%) lameness improved between the first and second examination and in 10 horses (91\%) between the first and third examinations. Eight of 12 horses were sound at the end of the trial. There was a general trend for reduction in the severity of MRI abnormalities during the study period. Calcium dobesilate is a potential treatment option for horses with foot pain associated with increased signal intensity in fat suppressed images in the spongiosa of the NB. The results of this pilot study suggest that a double blind controlled clinical trial into the effectiveness of CD is warranted.
\end{abstract}

Keywords: horse / navicular disease / Calcium dobesilate / MRI / bone oedema

Zur Wirkung von Calcium dobesilat bei Pferden mit einem im MRT erhöhten fettunterdrücktem Signal im Strahlbein: Pilotstudie

Im Zusammenhang mit chronischen Lahmheiten werden immer wieder erste Anzeichen von Strahlbeinerkrankung beobachtet. Diese frühzeitigen Erkrankungen werden im Magnetresonanztomographen (MRT) mit einem erhöhten fettunterdrücktem Signal im Strahlbein dargestellt. Für Calcium dobesilat (CD) wies man einen druckdynamischen Effekt im subchondralen Knochen in Gelenken von Kaninchen mit Osteoarthritis nach und es kann potentiell eine Behandlungsmethode bei frühzeitigen Strahlbeinerkrankungen bei Pferden darstellen. Ziel dieser Pilotstudie war es, die Lahmheit und die MRT-Veränderungen in 12 mit CD behandelten Pferden, mit diagnostizierter chronischer Strahlbeinlahmheit und einem im MRT erhöhten fettunterdrücktem Signal im Strahlbein, zu beobachten. Für die Untersuchung wurden 12 Pferde mit Vorderhandlahmheiten selektiert, die Lahmheitsdaver beschränkte sich auf einen Monat bis zwei Jahre. Einschlusskriterien waren: Keine röntgenologischen Veränderungen in den Standard Projektionen und ausschließlich ein im MRT erhöhtes fettunterdrücktes Signal im Strahlbein ohne gleichzeitig auftretende Defekte im MRT in der distalen Pferdegliedmaße. Die Pferde wurden mit Calcium dobesilat behandelt und nach einem einheitlichen kontrollierten Plan bewegt. Nach gestellter Diagnose erfolgte eine klinische und eine MRT-Nachuntersuchung im zweiten und im vierten Monat. Zwischen der ersten und der zweiten Untersuchung zeigten 10 von 12 Pferden (83\%), zwischen der zweiten und der dritten Untersuchung zeigten 10 Pferde (91\%) eine reduzierte Lahmheit. Am Ende der Pilotstudie waren 8 von 12 Pferden lahmheitsfrei. Während der Pilotstudie konnte im MRT eine Tendenz für eine Reduktion des fettunterdrückten Signals im Strahlbein festgestellt werden. Calcium dobesilat ist eine potentielle Behandlungsoption bei Pferden mit einem im MRT erhöhten fettunterdrücktem Signal im Strahlbein. Die Ergebnisse dieser Pilotstudie berechtigen eine Durchführung einer Doppelblindstudie zur weiteren Untersuchung der Effektivität von Calcium dobesilat.

Schlüsselwörter: Pferd / Strahlbeinerkrankung / Calcium dobesilat / MRT / Knochenödem

\section{Introduction}

Magnetic Resonance Imaging (MRI) has improved the diagnosis of foot pain originating from the area of the NB in horses because this imaging technique enables the clinician to differentiate soft tissue from bone lesions (Widmer et al. 2000, Tucker and Sande 2001, Dyson et al. 2003a and b, Dyson et al. 2005, Murray et al. 2006, Dyson and Murray 2007, Sherlock et al. 2007, Sherlock et al. 2008). Patholo- gical lesions of the NB can be identified in the absence of radiographic changes and with no detectable abnormalities of the flexor fibrocartilage or cortex, but with diffuse abnormalities of the medulla characterised by increased signal intensity in fat suppressed images including the short tau inversion recovery (STIR) sequence. This may reflect a variety of pathological processes including fibrosis, necrosis, bone oedema or abnormal trabecular modelling (Murray et al. 2006). 
In humans, increased signal intensity in the NB of the tarsus is associated with a wide variety of stress injuries to the bone, which are often painful enough to disturb an athlete's abilitiy to compete (Lassus et al. 2002). These authors found that the intraosseus hydrostatic pressure was increased in athletes having symptoms related to bone stress. They hypothesised that repetitive loading caused a compartmentsyndrome-like condition, associated with poor blood supply, ischaemia and low $\mathrm{pH}$; resulting in enhanced bone resorption and reduced new bone formation, which eventually results in focal bone necrosis. Core decompression by drilling the affected bone is an accepted treatment method for this condition in humans (Lassus et al. 2002, Radke et al. 2001).

A similar pathogenesis has been suggested for the development of ND in horses. It has been hypothesised that impaired venous drainage causes venous hypertension in the bone marrow resulting in intraosseous hypertension and bone oedema (Svalastoga and Smith 1983, Pleasant et al. 1993, Hertsch and Maaß 2009). Anecdotal reports have suggested that the accumulation of osmotically active proteins in the subchondral tissue leads to a compartment syndrome within the subchondral bone which is characterised by increased tissue pressure, acidosis, pain and a vicious cycle of progressive pathological changes (Miles et al. 2011). Surgical procedures have been explored to decompress the medullary cavity of the NB in sound horses (Jenner 2007, Jenner and Kirker-Head 2011). An experimental study revealed that drilling the bone reduced excessive intraosseous hydrostatic pressure by lowering perfusion resistance and improving local blood circulation. However the direct decompression effects were observed to be short-lived due to the rapid healing of the drill channels (Jenner 2007, Jenner and KirkerHead 2011).

Effective and specific medical treatment methods for lameness due to ND are currently not available, partly because the aetiopathogenesis of bone oedema in the NB is poorly understood. Currently tiludronate (a bisphosphonate) is widely used for similar bone pathologies in horses (Denoix et al. 2003, Schulze 2005, Delguste et al. 2007). The most important mechanism of action of bisphosphonates is to regulate bone metabolism through inhibition of bone resorption (Fleisch 1998). Biphosphonates may help to normalise metabolism in bone injuries characterized by abnormal absorption and formation, but they probably have no detectable effect on pressure dynamics in bone oedema.

Calcium 2,5-dihydroxybenzene sulfonate (CD) is a synthetic venoactive drug with a variety of biochemical functions including inhibition of serotonin, bradykinin, free radicals and histamine-induced capillary permeability; inhibition of prostaglandin and thromboxane synthesis; reduction of experimental lymphoedema and intralymphatic pressure; increased lymphatic flow; decreased angiogenesis; and reduced albumin leakage (Tejerina and Ruiz 1998). It has been used to treat high protein oedema in humans (Widmer et al. 1990, Clement 2000, Arceo et al. 2002, Kaur et al. 2003). The suggested mode of action is a macrophage-driven removal of osmotically active proteins, which has been described in models of lymphoedema in rats (Casley-Smith and CasleySmith 1985).
In a recent experimental study of an osteoarthritis model in rabbit knees, the intramedullary pressure dynamics and joint characteristics were investigated. In this model CD had a detectable effect on pressure dynamics in the subchondral bone of osteoarthritic joints (Miles et al. 2011).

Anecdotal reports suggest positive clinical effects of $C D$ in horses affected by ND, in the absence of adverse effects of the drug (Fricker 2007). Benzopyrone, a chemically very similar and similarly acting substance to CD (without a pyrone ring), has been successful used to treat subchondral cyst-like lesions in horses (Jackson et al. 2006).

Advances in MRI diagnosis in the foot suggest a different aetiopathogenesis for ND to those previously suggested, but there is a lack of targeted treatment options for specific pathological processes affecting the NB. The aim of this pilot study was to monitor clinical and MRI findings in horses with lameness associated with increased signal intensity in fat suppressed images in the medulla of the NB treated with CD.

\section{Animals, Materials and Methods}

Horses presented to two equine clinics for investigation and treatment of forelimb lameness between 2008 and 2010 were initially available for analysis. These horses underwent lameness investigation, followed by radiography and magnetic resonance imaging (MRI) of the feet.

The lameness assessment was performed at trot on hard ground in a straight line and being led on a circle, using the 10 point scale of the British Equine Veterinary Association (BEVA) lameness score (Dyson 2011 ).

Standard radiographic views (lateromedial; dorsoproximalpalmarodistal oblique (one exposed and collimated for the pedal bone and one for the navicular bone, palmaroproximal-palmarodistal oblique) were taken of both front feet. Radiographs were reviewed by an experienced observer.

Both front feet were examined in the standing sedated horse using Hallmarq's ${ }^{\circledR}$ low-field (0.27 Tesla) MRI-System (Hallmarq Veterinary Imaging, Guildford, England). The following MRI-Sequences were used: T1 Gradient Echo-weighted sagittal, T2 Gradient Echo-weighted transverse oblique, T1 Gradient Echo-weighted frontal/dorsal, T2* Gradient Echoweighted sagittal, T2* Gradient Echo-weighted transverse oblique, T2* Gradient Echo-weighted frontal/dorsal, T2 Fast Spin Echo-weighted transverse, STIR Fast Spin Echo sagittal, STIR Fast Spin Echo transverse oblique. Images were reviewed by an experienced observer.

Criteria for inclusion in the study were all of the following:

- Having forelimb lameness localised to the foot by either palmar digital or abaxial sesamoid perineural anaesthesia.

- Having lameness duration of at least one month, up to a maximum of two years.

- Having no abnormalities identified on standard radiographic projections of the feet (Butler et al 2008). 


\begin{tabular}{|c|c|c|c|c|}
\hline \multicolumn{5}{|c|}{ Details of cases in the study } \\
\hline Case & Breed & Gender & Age (years) & Use \\
\hline 1 & STB & Male & 7 & 1 \\
\hline 2 & TB & Male & 9 & 3 \\
\hline 3 & IS & Female & 7 & 3 \\
\hline 4 & IS & Male & 13 & 2 \\
\hline 5 & TB & Male & 8 & 1 \\
\hline 6 & IS & Female & 8 & 3 \\
\hline 7 & WS & Male & 14 & 1 \\
\hline 8 & IS & Female & 8 & 2 \\
\hline 9 & AA & Female & 10 & 1 \\
\hline 10 & $\mathrm{CC}$ & Female & 12 & 2 \\
\hline 11 & IS & Male & 8 & 2 \\
\hline 12 & TB & Female & 11 & 3 \\
\hline
\end{tabular}

$\mathrm{TB}=$ Thoroughbred, $\mathrm{STB}=$ Standardbred, IS = Irish Sports Horse, $\mathrm{AA}=$ Anglo Arab, CC = Cob cross, WS = Welsh section D; Use: $1=$ General, $2=$ Jumping, $3=$ Eventing

- Having MRI diagnosed abnormalities in the medulla of one or both navicular bones characterised by increased signal intensity in fat suppressed images and a hypointense signal in T1-weighted images.

- Having no other abnormalities detected during MRI examination.

Twelve horses fitted the inclusion criteria, details of their, ages, breeds and uses are shown in table 1 .

The owners of these horses were informed about the nature of the clinical trial and after their consent the horses were admitted to the study.

\section{Treatment}

Treatment consisted of $3 \mathrm{mg} / \mathrm{kg}$ CD p.o. BID in the first two months followed by $3 \mathrm{mg} / \mathrm{kg}$ CD p.o. SID in the third and fourth months. Calcium dobesilate was added to the feed or orally administered with a dosing syringe. Horses underwent regular foot trimming at an interval of 6 to 8 weeks, but no changes in the type of shoeing were permitted. In the first month the exercise regimen consisted of hand walking for up to one hour per day. During the second month the horses had ridden walking exercise. Months three and four consisted of ridden exercise at the walk and trot. Short periods of canter were included in the fourth month of the exercise regimen to bring the horse back to its previous levels of exercise. Horses had free access to pasture throughout.

\section{Follow up}

Assessment of lameness and MRI were repeated 2 months and 4 months after inclusion in the study.

\section{Evaluation of MRI scans}

From each fat suppressed (STIR) sequence, from each horse at each examination three sagittal scan images were selected
(One in the axial plane, and two approx. $1.5 \mathrm{~cm}$ lateral and medial to the midline, respectively). The scans were assigned with a random number and all other information was removed. The images were then reviewed by two different experienced observers, who were blinded to any information about the images. The scans were evaluated using three different scoring methods for the signal intensity in the NB:

- Percentage of area of NB with increased signal intensity in fat suppressed images.

- Increased signal intensity in fat suppressed images in whole section of the NB (score $1=$ no STIR signal, score $10=$ highest possible STIR signal intensity).

- Intensity scores (as above) following subdivision of the NB into four different quadrants a-d (Figure 1): a. Dorso-distal border of NB including the articular surface, b. Dorso-proximal border of NB including the articular surface, c. Palmar-distal border of NB including the flexor surface and $d$. Palmar-proximal border of NB including the flexor surface.

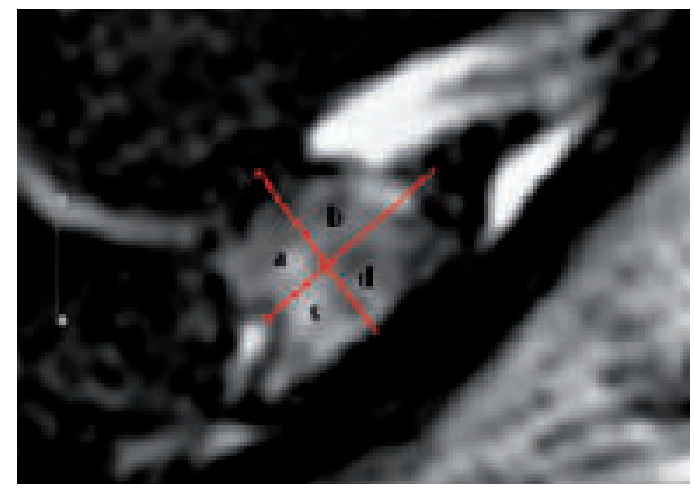

Fig. 1 Sagittal MRI scan of the navicular bone (NB), showing subdivision into four quarters a-d: a. distal border of NB including the articular surface, b. proximal border of NB including the articular surface, c. distal border of NB including the flexor surface, d. proximal border of NB including the flexor surface

Sagittaler MRT Scan des Strahlbeins zeigt die Unterteilung in vier Quarters a-d: a. distales Strahlbeinvientel an die Gelenksfläche angrenzend, b. proximales Strahlbeinviertel an die Gelenksfläche angrenzend, c. distales Strahlbeinviertel an die Beugesehne angrenzend, $d$. proximales Strahlbeinviertel an die Beugesehne angrenzend. 
Table 2 Lameness score in straight line for each horse and each selected forelimb at the three different examination times. Shading describes change in lameness score compared to first examination - light grey represents improvement in level of lameness, whilst dark grey demonstrates no change in level of lameness. Limbs selected for statistical analysis in fat.

Lahmheitsbewertung für jedes Pferd und jede ausgewählte Vordergliedmaße für alle drei Untersuchungszeitpunkte. Schattierungen beschreiben Veränderungen der Lahmheitsbewertung im Vergleich zu der ersten Untersuchung - Lahmheitsverbesserung ist in hellgrau dargestellt, keine Lahmheitsveränderung ist in dunkelgrau dargestellt. Gliedmaßen für die Statistische Analyse in Fett.

\begin{tabular}{|c|c|c|c|c|c|c|}
\hline \multirow[t]{2}{*}{ Case } & \multirow{2}{*}{$\begin{array}{l}\text { Lameness score out of } 10 \text { at presentation } \\
\qquad R\end{array}$} & \multicolumn{3}{|c|}{ Lameness score out of 10 at Examination 2} & \multicolumn{2}{|c|}{ Lameness score out of 10 at Examination 3} \\
\hline & & $\mathrm{L}$ & $R$ & $\mathrm{~L}$ & $\mathrm{R}$ & $\mathrm{L}$ \\
\hline 1 & 1 & 1 & 1 & 1 & 1 & 1 \\
\hline 2 & 1 & 1 & 0 & 0 & 0 & 0 \\
\hline 3 & 2 & 2 & 0 & 0 & - & - \\
\hline 4 & 0 & 2 & 0 & 2 & 0 & 1 \\
\hline 5 & 1 & 1 & 0 & 0 & 0 & 0 \\
\hline 6 & 2 & 2 & 0 & 0 & 0 & 0 \\
\hline 7 & 3 & 0 & 1 & 0 & 0 & 0 \\
\hline 8 & 0 & 4 & 0 & 2 & 0 & 1 \\
\hline 9 & 3 & 3 & 1 & 1 & 1 & 1 \\
\hline 10 & 4 & 4 & 0 & 0 & 0 & 0 \\
\hline 11 & 1 & 0 & 0 & 0 & 0 & 0 \\
\hline 12 & 2 & 0 & 0 & 0 & 0 & 0 \\
\hline
\end{tabular}

\section{Statistical analysis}

Prior to analyses, a single limb was chosen per horse to clarify comparisons and to remove within horse effect during follow-up evaluation. The limb was selected as either the lamest limb, or in bilateral equal lameness it was selected using a random number generator $(n=12)$ (Excel $\left.2010^{\circledR}\right)$.

Three questions were proposed:

- Is there a predilection site in the NB for increased signal intensity?

- Does the level of increased signal intensity reduce over time in horses treated with CD?

- Is lameness associated with increased signal intensity?

To identify predilection sites for increased signal intensity the MRI results for different regions of the NB were plotted graphically. To determine whether an increased signal intensity reduced over time; the measures of an increased signal intensity were identified as: Percentage and Intensity. For each horse, the maximum measure of each score from each sagittal position was identified at each examination time. The maximum scores were then compared between each examination time, for both measures of increased signal intensity, using Kruskal-Wallis tests.

To determine whether lameness was associated with increased signal intensity, horses were first categorised as either lame (lameness grade $>1 / 10$ ) or not lame (lameness grade $<1 / 10)$. Mann-Whitney tests were performed to assess whether lame horses had different levels of increased signal intensity compared to non-lame ones (using the maximum from the three sagittal positions, for the Percentage and Intensity measures of increased signal intensity).

Statistical analysis was performed using Stata ${ }^{\circledR}$ version 11 software. A significance level of $\mathrm{P}<0.05$ was chosen.

\section{Results}

All 12 cases returned for the second examination. One case (3) did not return for the third lameness evaluation or scan.

\section{Lameness scores}

The results of the lameness examinations are shown in Table 2 , with the single limbs selected for analysis highlighted. The lameness scores ranged from 1 to 4 out of 10 on the first examination, with a median of 2. Improvement of lameness score was seen in 10/12 horses (83\%) between the first and second examinations and in 10/11 (91\%) between first and third examinations. The other horses' levels of lameness remained unchanged. Eight of 12 horses were sound at the last examination. The distribution of lameness scores for the whole group at each examination time is shown graphically in Figure 2.

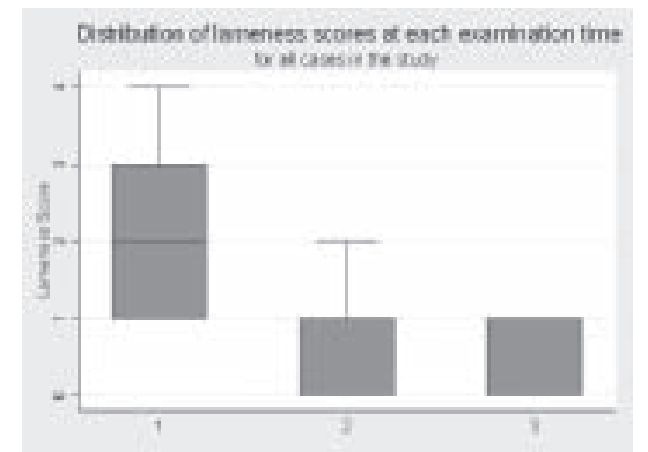

Fig. 2 Box plot showing the distribution of lameness scores ( $y$ axis) at each examination time ( $x$-axis) for all cases in the study. Boxes represent 25th to 75th percentiles, middle line represents the median, upper whisker represents the upper adjacent value.

Boxplots zeigen die Distribution der Lahmheitsbewertung (y-Achse) zu jedem Untersuchungszeitpunkt für alle Fälle in der Studie. Boxes präsentieren 25 bis 75 Perzentil, mittlere Linie präsentiert den Median, oberste Linie präsentient den Grenzwert. 


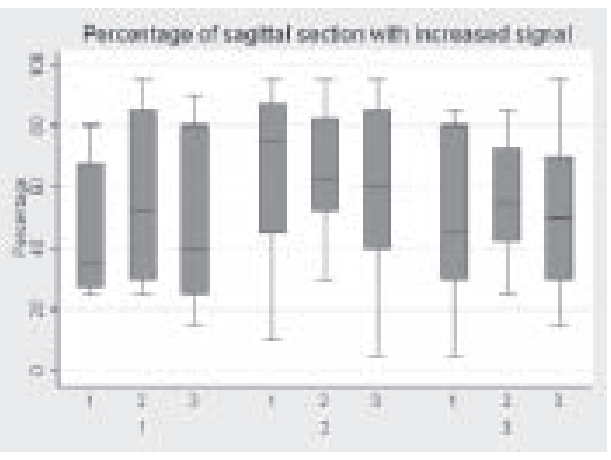

Fig. 3 Box plot showing results of "Percentage-score" at the different sagittal positions of the navicular bone (large 1-3; 1 = medial abaxial plane; 2 = axial plane; 3 = lateral abaxial plane) at each examination time (smaller 1-3). Boxes represent 25th to 75th percentiles, middle line represents the median, upper and lower whiskers represent the upper and lower adjacent values respectively. Boxplots zeigen die Ergebnisse des "Prozent Score" zu den unterschiedlichen sagittalen Positionen des Strahlbeins (Groß 1-3; $1=$ medial abaxiale Ebene; 2 =axiale Ebene; 3 =lateral abaxiale Ebene) zu jedem Untersuchungszeitpunkt (Klein 1-3). Boxes präsentieren 25 bis 75 Perzentil, mittlere Linie präsentiert den Median, oberste und unterste Linie präsentieren den Grenzwert.

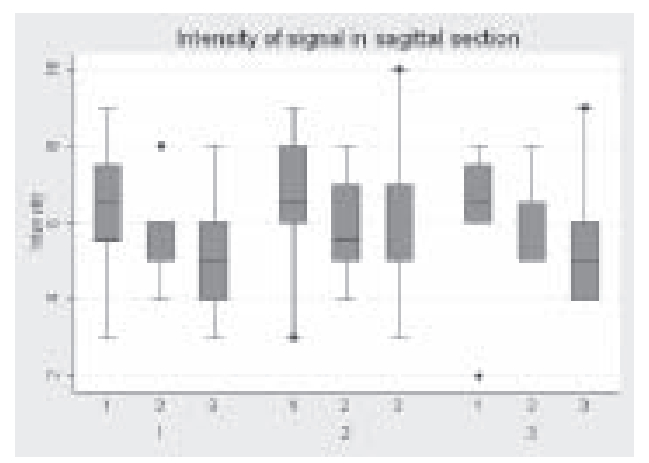

Fig. 4 Box plot showing results of "Intensity" at the different sagittal positions of the navicular bone (large 1-3;1 = medial abaxial plane; 2 =axial plane; 3 = lateral abaxial plane) at each examination time (smaller 1-3). Boxes represent 25 th to 75 th percentiles, middle line represents the median, upper and lower whiskers represent the upper and lower adjacent values respectively, dots represent outliers.

Boxplots zeigen die Ergebnisse der "Intensität" "zu den unterschiedlichen sagittalen Positionen des Strahlbeins (Groß 1-3; 1 = medial abaxiale Ebene; 2 = axiale Ebene; 3 =lateral abaxiale Ebene) zu jedem Untersuchungszeitpunkt (Klein 1-3). Boxes präsentieren 25 bis 75 Perzentil, mittlere Linie präsentient den Median, oberste und unterste Linie präsentieren den oberen und unteren Grenzwert, Punkte präsentieren Ausreißer.

\section{Predilection site for increased signal intensity}

Figures 3-5 present graphical representations of the results of MRI analyses. There was a general trend for higher scores (Percentage and Intensity) in the axial sections compared to the lateral or medial sections for both measures of an increased signal intensity. The scores for each quadrant subdivision of the NB are shown graphically in Figure 5. Sections a and $c$ demonstrated a trend for higher MRI scores than sec-
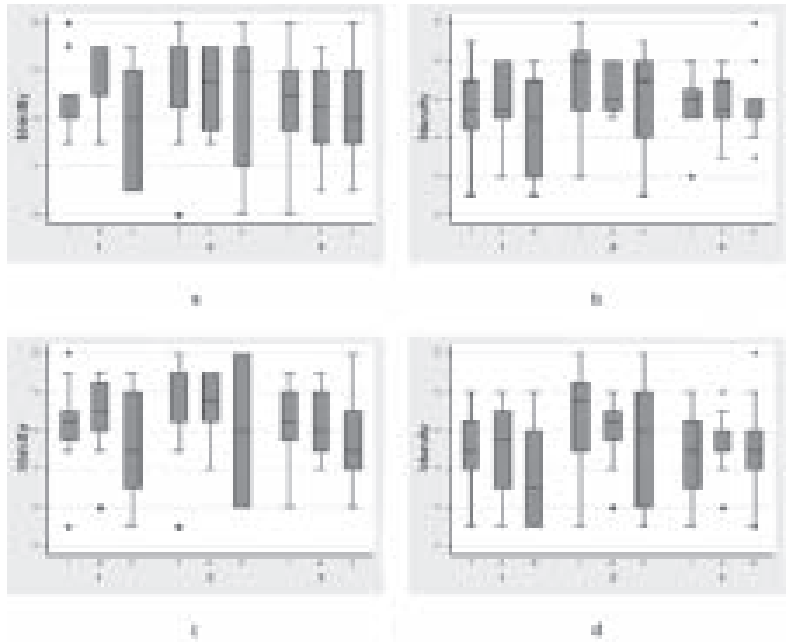

Fig. 5 Box plots demonstrating STIR intensity scores from different quarters (a-d) at each of three sagittal positions (large numbers $\mathrm{x}$-axis; $1=$ medial abaxial plane; $2=$ axial plane; 3 = lateral abaxial plane) of the navicular bone, at different examination times (small numbers $x$-axis). $a=$ distal border of NB including the articular surface, $b=$ proximal border of NB including the articular surface, $c$ $=$ distal border of NB including the flexor surface, $\mathrm{d}=$ proximal border of NB including the flexor surface. Boxes represent 25th to 75th percentiles, middle line represents the median, upper and lower whiskers represent the upper and lower adjacent values respectively, dots represent outliers.

Boxplots demonstrieren erhöhte Signalintensität in fettunterdrückten Scans der vier verschiedenen Quarter (a-d) zu jeder der drei sagittalen Positionen (große Nummern $x$-Achse; 1 = medial abaxiale Ebene; 2 = axiale Ebene; 3 =lateral abaxiale Ebene) des Strahlbeins zu jedem Untersuchungszeitpunkt (kleine Nummern $x$-Achse). $a=$ distales Strahlbeinviertel an die Gelenksfläche angrenzend, $b=$ proximales Strahlbeinviertel an die Gelenksfläche angrenzend, $c=$ distales Strahlbeinviertel an die Beugesehne angrenzend, $d=$ proximales Strahlbeinviertel an die Beugesehne angrenzend. Boxes präsentieren 25 bis 75 Perzentil, mittlere Linie präsentiert den Median, oberste und unterste Linie präsentieren den oberen und unteren Grenzwert, Punkte präsentieren Ausreißer.
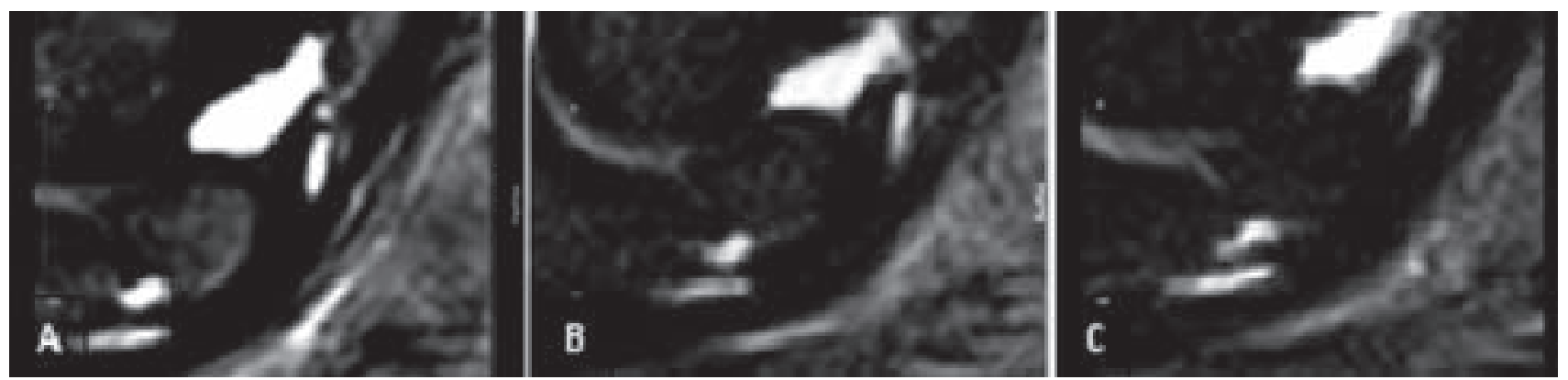

Fig. 6 Fat suppressed images of the navicular bone before (A) and two (B) and four (C) months after treatment with Calcium dobesilate showing a reduction in Percentage of bone affected and intensity of the signal in the medullary cavity over time (Case 10).

Fettunterdrückte Aufnahmen des Strahlbeins bevor (A), zwei Monate (B) und vier Monate während der Behandlung mit Calcium dobesilate zeigen im Verlauf eine Signalreduktion in Prozent und Intensität in der Markhöhle des betroffenen Knochens (Fall 10). 
tions $b$ and $d$, however there were no significant differences between the sites examined.

Change in increased signal intensity between examinations There was a general trend of decreasing signal intensity between examinations one to three (Figure 6). However there was no statistically significant difference in maximum percentage or maximum intensity between the three examination times $(p=0.77$ and $p=0.09$ respectively) indicating that there is no strong statistical evidence that these measures changed between examinations.

Correlation between lameness and increased signal intensity There was no significant association between lameness and either of the scores of increased signal intensity: Percentage score $(p=0.31)$; Intensity score $(p=0.08)$. Based on these results there is not significant evidence that an increased signal intensity is associated with lameness.

\section{Discussion}

This pilot study documented the lameness scores and the MRI findings of twelve horses with navicular disease treated with CD. The four months follow up examinations revealed an improvement of lameness in 10 of 11 horses and a reduction in signal intensity within the medullary cavity in fat suppressed images. The causes of increased signal intensity in fat suppressed images of the NB in horses are poorly understood, but are thought to be associated with pathological processes within the bone. Although not statistically significant; a trend for reduction in signal intensity was observed between examinations and in non-lame compared to lame horses. In contrast the percentage of sections measure did not show a clear relationship with examination time or lameness. The reason for this difference is unknown, but could potentially be the result of the percentage measure of an increased signal intensity being slower to respond to changes in the NB, or being a less useful measure of pathology.

In this case series the highest signal scores were detected in the axial section of the NB, an area of high mechanical loading, which might explain the increased signal at this site (Blunden et al 2006, Blunden et al 2009).

The distal quadrants adjacent to the DSIL also showed higher scores for percentage affected and signal intensity compared to the proximal quadrants. This may be because these areas are subjected to higher mechanical loads, or because these areas are affected by impairment of venous drainage to a greater degree than more proximal areas in the bone. Advanced histological techniques would be required to investigate differences in signal intensity within the same cross section of the medullary cavity of the NB and to evaluate involvement of the DSIL and/or the sesamoid canals in the pathogenesis.

The lameness grade improved in all but one horse of this study. It has been recognised that objective assessment of low grade lameness is difficult (Keegan et al. 2010). In this study, only forelimb lameness's were examined which are considered easier to detect than hind limb lameness's and the lameness examinations were all performed by experienced observers. Future studies could potentially use more advanced techniques to assess and quantify the degree of lameness, such as motion capture technology.

In attempt to reduce bias, reviewers of the MRI scans were blinded for case and for time point and images were presented to them in a random order. In addition, (although initial MRI scans were evaluated for absence of concurrent pathology by an experienced clinician), the two reviewers only examined the medullary cavity of the NB in the fat suppressed images, in order to reduce the chance of them being affected by extraneous information.

Although signal intensity and lameness were not significantly correlated $(p=0.08)$, there did appear to be a trend for decreased intensity scores in sound horses compared to lame ones and it is possible that a significant correlation might be appreciated with a larger study population. If this is the case, assuming that increased signal intensity is the result of an intraosseus compartment syndrome (Lassus et al. 2002), CD may be useful in ameliorating the increased hydrostatic pressure and thus result in reduced levels of lameness, as observed in this study.

Whilst the improvement in lameness observed in this study is encouraging, without a control group, it is impossible to be sure that this was the result of the CD treatment. Orthopaedic shoeing and reduced levels of exercise are used in the convalescence of lame horses (Willemen et al. 1999). No significant changes to shoeing were allowed in the horses in this study, but it is possible that the exercise regimen alone may have resulted in the horses' clinical and MRI improvement. Further multivariable case control studies are warranted to investigate the use of this drug.

This pilot study was designed to assess the MRI scans of horses with early stages of ND treated with CD. There was a general trend for reduction of MRI signal in the fat suppressed images, which is encouraging. But further studies are required to understand the significance of such changes.

\section{Abbreviations}

$C D=$ calcium dobesilate; $N B=$ navicular bone; $N D=$ navicular disease; $\mathrm{IOP}=$ intraosseous pressure; $\mathrm{STIR}=$ short tau inversion recovery; $\mathrm{MRI}=$ Magnetic Resonance Imaging

\section{Source of Funding}

This study was supported in part by Scanvet: -follow-up scans and medications were sponsored by Scanvet, Fredensburg, Denmark.

\section{Manufacturers`address}

Dobavet GmbH, Schlyffistrasse 10, 8806 Bäch, Swiss

\section{References}

Arceo A., Berber A. and Trevino C. (2002) Clinical evaluation of the efficacy and safety of calcium dobesilate in patients with chronic venous insufficiency of the lower limbs. Angiology 53, 539-544 
Blunden A., Dyson S., Murray R. and Schramme M. (2006) Histopathology in horses with chronic palmar foot pain and age-matched controls. Part 1: Navicular bone and related structures. Equine Vet. J. 38, 15-22

Blunden A., Murray R. and Dyson S. (2009) Lesions of the deep digital flexor tendon in the digit: a correlative MRI and post mortem study in control and lame horses. Equine Vet. J. 41, 25-33

Butler J., Colles C., Dyson S., Kold S. and Poulos P. (2008) Clinical Radiology of the Horse, Blackwell Wiley, 3rd Edition, Chapter 3, 53-188

Casley-Smith J. and Casley-Smith J. (1985) The Effects of Calcium Dobesilate on acute Lymphedema (with and without Macrophages), and on burn edema. Lymphology 18, 37-45

Clement D. L. (2000) Management of venous edema: insights from an international task force. Angiology 51, 13-17

Delguste C., Amory H., Doucet M., Piccot-Crezollet C., Thibaud D., Garnero P., Detilleux J. and Lepage O. M. (2007) Pharmacological effects of tiludronate in horses after long-term immobilization. Bone 41, 414-421

Denoix J. M., Thibaud D. and Riccio B. (2003) Tiludronate as a new therapeutic agent in the treatment of navicular disease: a doubleblind placebo-controlled clinical trial. Equine Vet. J. 35, 407-413

Dyson S. (2011) Can lameness be graded reliably? Equine Vet. J. 43, 379-382

Dyson S. and Murray R. (2007) Magnetic resonance imaging evaluation of 264 horses with foot pain: The podotrochlear apparatus, deep digital flexor tendon and collateral ligaments of the distal interphalangeal joint. Equine Vet J 39, 340-343

Dyson S., Murray R. and Schramme M. (2005) Lameness associated with foot pain: results of magnetic resonance imaging in 199 horses (January 2001-December 2003) and response to treatment. Equine Vet. J. 37, 113-121

Dyson S., Murray R., Schramme M. and Branch M. (2003a) Lameness in 46 horses associated with deep digital flexor tendonitis in the digit: diagnosis confirmed with magnetic resonance imaging. Equine Vet. J. 35, 681-690

Dyson S., Murray R., Schramme M. and Branch M. (2003b) Magnetic resonance imaging of the equine foot: 15 horses. Equine Vet. J. $35,18-26$

Fleisch H. (1998) Bisphosphonates: mechanisms of action. Endocr. Rev. 19, 80-100

Fricker C. (2007) Personal communication

Hertsch B. and Maaß S. (2009) Aspects of the pathogenesis of podal arthritis of the horse as an important part of navicular syndrome. Pferdeheilkunde 25, 124-136

Jackson M., Fricker C. and Fürst A. (2006) Ein never medikamenteller Therapieansatz fuer die Behandlung von subchondralen Knochenzysten beim Pferd. In: DVG 19. Arbeitstagung der Fachgruppe Pferdekrankheiten, Hannover, Germany. pp 33-38

Jenner F. (2007) Navicular disease with core decompression - a new approach. In: ECVS Meeting, Dublin

Jenner F. and Kirker-Head C. (2011) Core Decompression of the Equine Navicular Bone: An In Vivo Study in Healthy Horses. Vet. Surg. 40, 152-162

Kaur C., Sarkar R., Kanwar A. J., Attri A. K., Dabra A. K. and Kochhar S. (2003) An open trial of calcium dobesilate in patients with venous ulcers and stasis dermatitis. Int. J. Dermatol. 42, 147-152

Keegan K., Dent E., Wilson D., Janicek J., Kramer J., Lacarrubba A., Walsh D., Cassells M., Esther T., Schiltz P., Frees K., Wilhite C., Clark J., Pollitt C., Shaw R. and Norris T. (2010) Repeatability of subjective evaluation of lameness in horses. Equine Vet. J. 42, 92-97.
Lassus J., Tulikoura I., Konttinen Y. T., Salo J. and Santavirta S. (2002) Bone stress injuries of the lower extremity: a review. Acta. Orthop. Scand. 73, 359-368

Miles J. E., Wenck A., Fricker C. and Svalastoga E. (2011) Modulation of the intramedullary pressure responses by calcium dobesilate in a rabbit knee model of osteoarthritis. Acta Orthop. 82, 622627

Murray R., Schramme M., Dyson S., Branch M. and Blunden T. (2006) Magnetic resonance imaging characteristics of the foot in horses with palmar foot pain and control horses. Vet. Radiol. Ultrasound 47, 1-16

Pleasant R., Baker G., Foreman J., Eurell J. and Losonsky J. (1993) Intraosseous pressure and pathologic changes in horses with navicular disease. Am. J. Vet. Res. 54, 7-12

Radke S., Vispo-Seara J., Walther M., EHI V. and Eulert J. (2001) Transient bone marrow oedema of the foot. International Orthopaedics 25, 263-267

Schulze T. (2005) Fallbericht: Seltene Diagnose und erfolgreiche Therapie. In: Pferdespiegel. pp 140-145

Sherlock C., Kinns J. and Mair T. (2007) Evaluation of foot pain in the standing horse by magnetic resonance imaging. Vet. Rec. 161, 739-744

Sherlock C., Mair T. and Blunden T. (2008) Deep erosions of the palmar aspect of the navicular bone diagnosed by standing magnetic resonance imaging. Equine Vet. J. 40, 684-692

Svalastoga E. and Smith M. (1983) Navicular disease in the horse. The subchondral bone pressure. Nord. Vet. Med. 35, 31-37

Tejerina T. and Ruiz E. (1998) Calcium dobesilate: pharmacology and future approaches. Gen. Pharmacol. 31, 357-360

Tucker R. and Sande R. (2001) Computed tomography and magnetic resonance imaging of the equine musculoskeletal conditions. Vet. Clin. North Am. Equine Pract. 17, 145-157

Widmer L., Biland L. and Barras J. P. (1990) Doxium 500 in chronic venous insufficiency: a double-blind placebo controlled multicentre study. Int. Angiol. 9, 105-110

Widmer W., Buckwalter K., Fessler J., Hill M., Vansickle D. and Ivancevich S. (2000) Use of radiography, computed tomography and magnetic resonance imaging for evaluation of navicular syndrome in the horse. Vet. Radiol. Ultrasound 41, 108-116

Willemen M., Savelberg H. and Barneveld A. (1999) The effect of orthopaedic shoeing on the force exerted by the deep digital flexor tendon on the navicular bone in horses. Equine Vet. J. 31, 2530

Imke Janssen

Veterinary Clinic for Horses

Essener Strasse 39 a

49456 Lüsche

Germany

jaimke@web.de

Prof. Christoph Lischer

Equine Clinic

Free University of Berlin

Oentzenweg $19 b$

14163 Berlin

Germany

christoph.lischer@fu-berlin.de 